\title{
EVALUASI KESESUAIAN LAHAN UNTUK TANAMAN TEBU PADA LAHAN KARST FORMASI WONOSARI (TMWL) KECAMATAN GEDANGAN KABUPATEN MALANG
}

\section{Evaluation of Land Suitability for Sugarcane in Wonosari Formation Karst Land (TMWL), Gedangan District, Malang Regency}

\author{
Pramudito Kartiko Dumipto, Mochtar Lutfi Rayes, Christanti Agustina* \\ Jurusan Tanah, Fakultas Pertanian, Universitas Brawijaya, Jl. Veteran 1 Malang, 65145 \\ *Penulis korespondensi: christanti.ag@ub.ac.id
}

\begin{abstract}
Karst landform has different soil properties than the others land which are high clay content, low water holding capacity, relatively low nutrient availability, and in some areas it has a shallow soil that can impact the suitability of sugarcane productivity. It is necessary to analyze the suitability classes of sugarcane on karst landform based on productivity and make the criteria of sugarcane on karst landform. Research was conducted in Gedangan District, Malang Regency, East Java Province, Indonesia with survey method (13 land map unit) with 38 minipits and 8 soil profil as typical pedon. The modification using boundary line method by multiple regression with stepwise method which has a value of $\mathrm{R}^{2} \geq 0,5$ and percentage production class. Land suitability at study area before modification has class S3 (Marginally Suitable) and N (Not Suitable). Boundary line method results land characteristics that significantly correlate with production (organic carbon, total $\mathrm{N}$, available $\mathrm{P}$, exchangeable $\mathrm{K}$, soil depth and slope). The boundary line method results class S2 (Moderately Suitable), S3 and $\mathrm{N}$ with accuration $75 \%$. The modification with percentage production class was done (organic carbon, total N, exchangeable K, and slope) and results class S1(Highly Suitable), S2, S3, and $\mathrm{N}$ with accuration $91 \%$.
\end{abstract}

Keywords : boundary line method, karst landform, land suitability, sugarcane productivity

\section{Pendahuluan}

Kebutuhan gula Indonesia setiap tahunnya cenderung meningkat seiring dengan berkembangnya zaman dan makin bertambahnya jumlah penduduk Indonesia. Menurut Kementerian Perindustrian (2017), selama 5 tahun terakhir (2013 - 2017) kebutuhan gula (konsumsi rumah tangga dan industri) meningkat sebesar 0,2 juta ton. Berdasarkan kondisi tersebut, pemerintah mengeluarkan program swasembada gula dengan menargetkan Indonesia untuk memenuhi kebutuhan gula sendiri tanpa impor dari negara lain. Program swasembada gula dapat dicapai dengan melakukan perluasan lahan tebu di Indonesia. Perluasan lahan tebu dilakukan dengan menambah luasan / areal lahan untuk ditanami tanaman tebu di Indonesia. Di Jawa, lahan tebu sudah banyak tersebar di berbagai provinsi salah satunya Provinsi Jawa Timur.

Lahan tebu di Jawa Timur saat ini tercatat seluas 203.566 ha, yang terdiri dari perkebunan tebu rakyat 184.211 ha, perkebunan tebu negara 18.950 ha dan perkebunan swasta 656 ha. Kabupaten Malang merupakan salah satu sentra penghasil tebu di Provinsi Jawa Timur. Menurut Dinas Pertanian dan Perkebunan Kabupaten Malang (2016) selama 5 tahun terakhir (2012 - 2016) tebu Kabupaten Malang memiliki rata - rata produktivitas mencapai 90 ton/ha. Salah satu daerah sentra produksi tebu di Kabupaten Malang adalah Kecamatan Gedangan. Tanaman tebu di Kecamatan 
Gedangan Kabupaten Malang banyak dibudidayakan pada lahan dengan landform karst yang termasuk kedalam Formasi batuan Wonosari (Tmwl). Formasi Wonosari merupakan salah satu formasi di zona fisiografi regional pegunungan selatan Jawa yang berumur miosen-pliosen dengan komposisi batuan berupa batu gamping, batu gamping napal tufaan, batu gamping konglomerat, batupasir tufaan dan batu lanau (Surono et al., 1992). Karst Kecamatan Gedangan masuk kedalam sub zona Gunung Sewu dengan bukit batu gamping membentuk kerucut dengan ketinggian puluhan meter (Van Bemmelen, 1949).

Lahan tebu di Kecamatan Gedangan selama 5 tahun terakhir memiliki rata - rata produktivitas tebu sebesar 85,16 t ha-1 (2012 2016) (Dinas Pertanian dan Perkebunan Kabupaten Malang, 2016). Varietas yang ditanam sebagian besar merupakan varietas $\mathrm{BL}$ atau Bululawang dengan potensi produksi yaitu 94,3 ton/ha (secara nasional). Varietas BL dipilih dikarenakan memiliki kadar gula yang tinggi dibanding varietas yang lain (Rukmana, 2015). Menurut wawancara petani, produksi tebu BL pada Kecamatan Gedangan memiliki variasi produksi $23-80 \mathrm{t} \mathrm{ha}^{-1}$ dan sebagian besar masih tergolong lahan dengan produktivitas tebu rendah. Hal ini mungkin disebabkan karena landform karst yang terdapat pada lokasi penelitian. Landform karst memiliki sifat tanah yang berbeda dengan lahan lain dimana memiliki kandungan liat tinggi dan kapasitas menyimpan air rendah (kehilangan air), ketersediaan hara yang relatif rendah. Di beberapa daerah memiliki solum tanah dangkal, dan kesesuaiannya juga berbeda dengan lahan lain, untuk itu diperlukan adanya penelitian tentang evaluasi kesesuaian lahan pada daerah karst dan juga menyusun kriteria kesesuaian lahan tanaman tebu khusus untuk daerah karst. Penyusunan kriteria kesesuaian lahan dilakukan karena selama ini kriteria kesesuaian lahan yang ada kadang tidak sesuai dengan produksi/produktivitas tanaman di lapangan.

\section{Bahan dan Metode}

Penelitian dilakukan di Kecamatan Gedangan, Kabupaten Malang, Jawa Timur, Indomesia, dengan batasan daerah representas bentuk lahan karst. Bentuk lahan karst terdapat di bagian selatan Kecamatan Gedangan, seperti tersaji dalam Gambar 1. Alat dan bahan untuk penelitian ini terdiri dari seperangkat laptop dengan beberapa software pemetaan dan pengolahan data, survei set untuk identifikasi morfologi tanah, seperangkat alat untuk analisis labolatorium untuk sifat fisika dan kimia tanah, dan buku kunci taksonomi tanah (Soil Survey Staff, 2014) untuk menentukan klasifikasi tanah. Penelitian dilakukan dengan metode survei fisiografi dengan dasar satuan peta lahan yang terdiri dari 13 satuan peta lahan. Identifikasi morfologi tanah dilakukan dengan pembuatan minipit pada 38 titik pengamatan dan 8 profil tanah sebagai pedon tipikal. 8 profil ini mewakili setiap landform daerah penelitian yang terdiri dari punthuk karst pada perbukitan karst, punggung karst pada perbukitan karst, pelembahan karst pada dataran karst, dan pelembahan karst pada perbukitan karst.

Contoh tanah diambil di setiap horizon ,mulai dari horizon bawah sampai dengan horizon atas secara komposit. Analisis sifat fisik tanah terdiri dari tekstur tanah (metode pipet). Analisis sifat kimia terdiri dari $\mathrm{pH}$ (pelarut $\mathrm{H}_{2} \mathrm{O}$ ), C-Organik (Walkley-Black), Basa-basa tertukar (ekstraksi $\mathrm{NH}_{4} \mathrm{OAc} 1 \mathrm{~N}$ pH7), kapasitas tukar kation (KTK, ekstraksi $\mathrm{NH}_{4} \mathrm{OAc} 1 \mathrm{~N} \mathrm{pH7)}$, dan kejenuhan basa (KB, $\Sigma(\mathrm{Ca}, \mathrm{Mg}, \mathrm{K}, \mathrm{Na}) / \mathrm{KTK} \times 100 \%), \mathrm{P}$ tersedia, salinitas, dan alkalinitas.

Analisis kesesuaian lahan dilakukan dengan matching kriteria kesesuaian lahan menggunakan program SPKL versi 2.1, dan dilakukan modifikasi kriteria menggunakan metode boundary line. Sebelumnya dilakukan analisis data terlebih dahulu menggunakan regresi berganda dengan metode stepwise untuk mengetahui karakteristik lahan yang berpengaruh signifikan terhadap produktivitas tebu di lapangan (nilai $\mathrm{R}^{2} \geq 0,5$ ). Validasi kelas kesesuaian lahan hasil modifikasi dilakukan menggunakan accuration assessment dengan rumus :

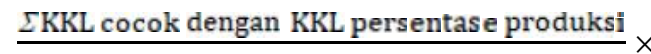
$100 \%$ 


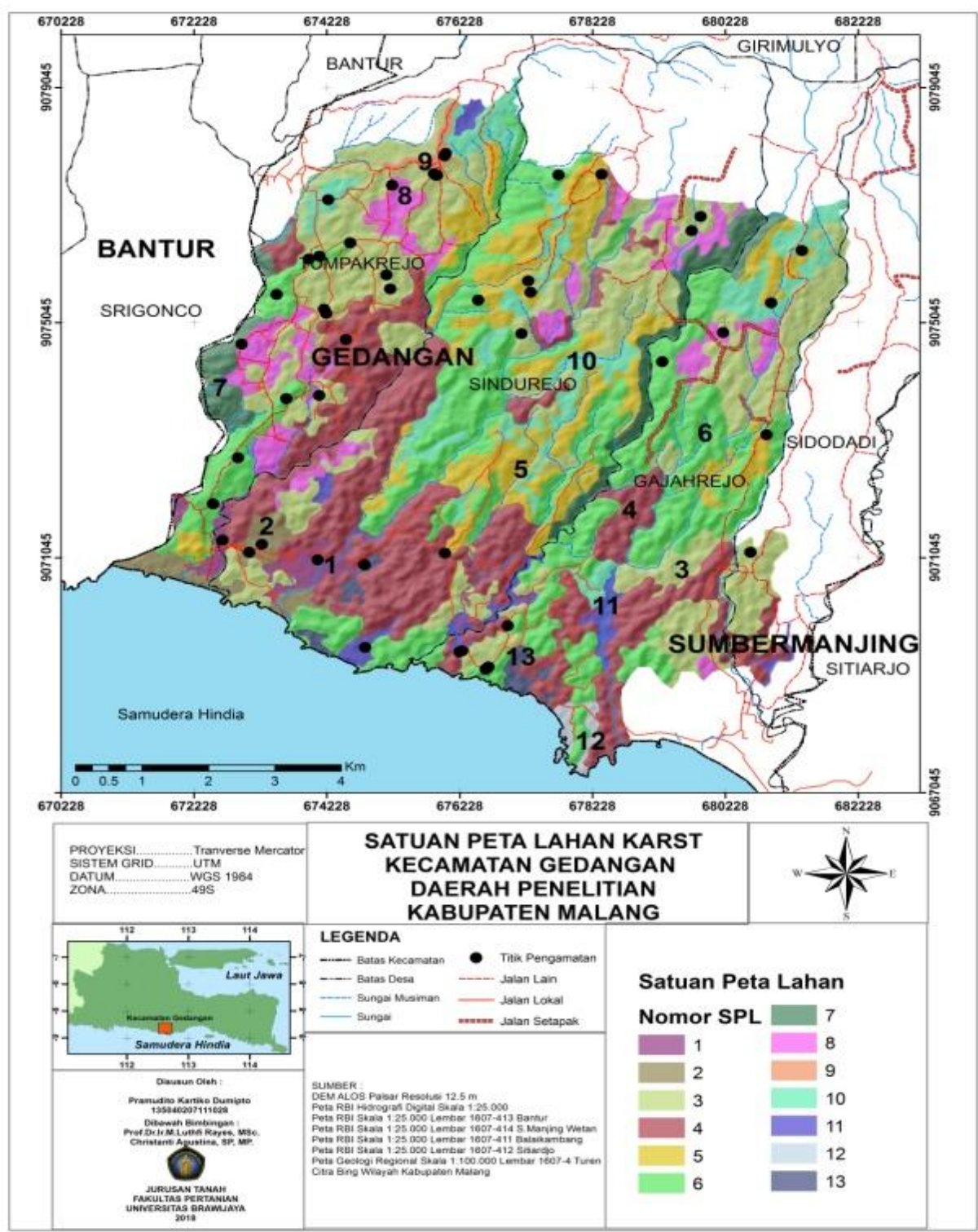

Gambar 1. Peta lokasi dan titik pengamatan.

\section{Hasil dan Pembahasan}

Kelas kesesuaian lahan aktual lahan karst per SPL berdasarkan Djaenuddin et al. (2003 \& 2011), Charrupat et al. (2002) dan Siswanto (2006)

Kelas kesesuaian lahan ditentukan berdasarkan hasil matcbing karakteristik lahan dengan kriteria kesesuaian lahan dengan menggunakan program SPKL versi 2.1 (Bachri et al., 2016). Pada penelitian ini, evaluasi lahan hanya dilakukan terhadap 10 SPL dan ketiga SPL berikutnya tidak dilakukan proses evaluasi lahan. Alasan tidak dilakukan evaluasi lahan untuk ketiga SPL yaitu SPL 11, SPL 12 dan SPL 13 dikarenakan pada ketiga SPL ini tidak ditanami komoditas tebu. Berikut merupakan hasil matching KKL tebu.

\section{Karakteristik lahan yang berpengaruh terhadap produktivitas tanaman tebu}

Hubungan $C$ - organik dengan produktivitas tanaman tebu

Gambar 2 menunjukkan adanya korelasi yang kuat antara C-organik dengan produktivitas tanaman tebu, dengan nilai determinasi $\mathrm{R}^{2}=$ 
0,6646 dan $\mathrm{r}=0,85$. Tanaman tebu akan menghasilkan produktivitas yang tinggi ketika c-organik berada pada angka $\geq 1,20 \%$, dan akan berada pada kelas S2, sedangkan tanaman tebu akan rendah produktivitasnya jika Corganik $\leq 0,60 \%$, dan akan berada pada kelas N.

Tabel 1. Hasil kelas kesesuaian lahan versi Djaenuddin et a. (2003 \& 2011), Charrupat et al. (2002) dan Siswanto (2006).

\begin{tabular}{cccc}
\hline SPL & Subgroup Tanah & $\begin{array}{c}\text { Sub Kelas } \\
\text { Kesesuaian Lahan }\end{array}$ & Faktor Pembatas \\
\hline 1 & Eutric Humudept & S3-na & P tersedia \\
2 & Typic Humudept & S3-na & P tersedia \\
3 & Typic Humudept & S3-na/eh & N-total, P tersedia, Lereng, Bahaya Erosi \\
4 & Typic Humudept & S3-na/eh & N-total, P tersedia, Lereng, Bahaya Erosi \\
P tersedia, Lereng, Bahaya Erosi \\
5 & Typic Humudept & S3-na/eh & Kedalaman tanah, N-total, P tersedia, \\
5 & Lithik Hapludoll & S3-rc/na/eh & Lereng, Bahaya Erosi \\
& & & Lereng \\
6 & Typic Hapludoll & N-eh & Lereng, Bahaya Erosi \\
7 & Lithik Hapludoll & N-eh & Drainase, P tersedia \\
8 & Typic Humudept & S3-oa/na & Kedalaman tanah, C-organik, N-total, P \\
9 & Typic Calciudoll & S3-rc/nr/na & tersedia, \\
& & P tersedia \\
10 & Typic Humudept & S3-na & Kedalaman tanah, N-total, P tersedia \\
10 & Typic Hapludoll & S3-rc/na & - \\
11 & Typic Humudept & - & - \\
12 & Typic Humudept & - & - \\
13 & Typic Humudept & - & \\
\hline Keterangan : : tidak dilakukan proses evaluasi lahan dikarenakan tidak terdapat komoditas tanaman tebu.
\end{tabular}

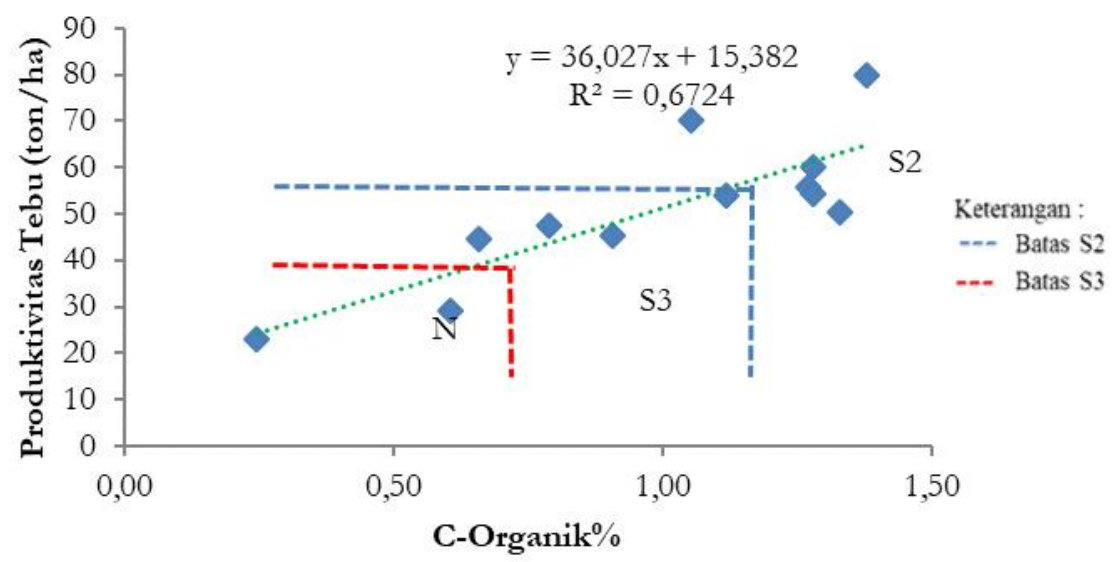

Gambar 2. Hubungan C-organik dan produktivitas tebu.

Menurut Chen dan Yung (1990), kandungan bahan organik mempunyai peran penting dalam usaha budidaya pertanian, hal ini disebabkan karena bahan organik dapat meningkatkan dan memelihara kesuburan kimia, fisika, maupun biologi tanah. Dalam memelihara kesuburan kimia bahan organik dapat meningkatkan KTK tanah, berfungsi sebagai cadangan sekaligus sumber hara makro dan mikro, mengikat kation yang mudah tersedia bagi tanaman tetapi menahan kehilangan hara akibat pencucian, juga 
berfungsi dalam pembentukan ikatan organic terhadap unsure mikro $\mathrm{Fe}, \mathrm{Zn}, \mathrm{Mn}$ sehingga tetap tersedia bagi tanaman (Tisdal et al., 1993). Selain itu bahan organik juga dapat meningkatkan ketersediaan beberapa unsur hara dan efisiensi penyerapan $\mathrm{P}$ (Chen dan Yung, 1990). Perannya dalam fisika tanah, bahan organik dapat meningkatkan daya menahan air, memperbaiki struktur tanah menjadi gembur, mencegah pengerasan tanah serta menyangga reaksi tanah dari kemasaman, kebasaan dan salinitas (Tisdale et al., 1993). Chen dan Yung (1990) juga menambahkan bahan organik tinggi dapat memudahkan pengolahan tanah serta dapat menahan butiran tanah dari proses erosi permukaan. Aspek biologi tanah, kandungan bahan organik tinggi dalam tanah dapat mendorong partumbuhan mikroba secara cepat sehingga dapat memperbaiki aerasi tanah, menyediakan energi bagi kehidupan mikroba tanah, meningkatkan aktivitas jasad renik (mikroba tanah), dan meningkatkan kesehatan biologis tanah (Tisdal et al., 1993; Zaini et al., 2004).

Hubungan $N$ total dengan produktivitas tanaman tebu

Gambar 3 menunjukkan bahwa N-total dengan produktivitas tanaman tebu memiliki hubungan yang positif dengan nilai koefisien determinasi atau $R^{2}$ sebesar 0,5688 dan $r=0,75$. Hubungan $\mathrm{N}$-total dengan produktivitas tanaman tebu berbanding lurus dimana ketika nilai $\mathrm{N}$-total bertambah maka akan diikuti pula kenaikan Produktivitas tanaman tebu, begitu pula sebaliknya.

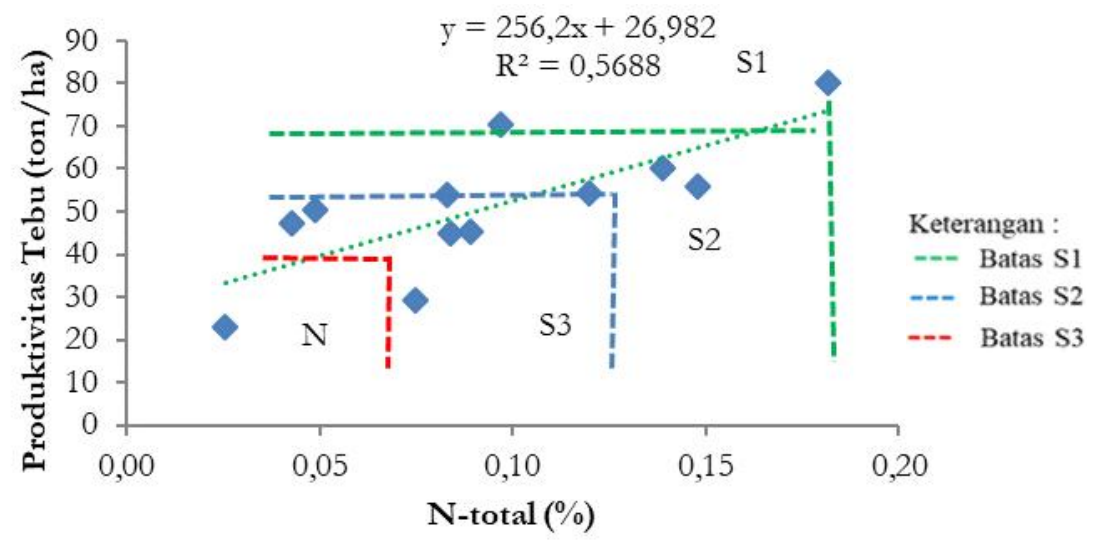

Gambar 3. Hubungan $\mathrm{N}$ total dengan produktivitas tebu.

Gambar 3 menunjukkan bahwa tanaman tebu akan berproduksi dengan baik dan berada pada kelas S1 pada kadar N-total sebesar lebih dari $0,18 \%$ dan pada kadar $\mathrm{N}$-total kurang dari $0,12 \%$ performa tanaman tebu akan mulai menurun (berada pada kelas S3 sampai N) dan semakin buruk jika menyentuh nilai $<0,04 \%$ dilihat dari produktivitas yang dihasilkan. Menurut Hardjowigeni (2005), sifat kimia tanah $\mathrm{N}$-total yang sesuai untuk tanaman tebu yaitu mempunyai nilai $\mathrm{N}$-total mulai dari 0,07 sampai 2,5\%. Tisdale et al. (1994) berpendapat jika suplai $\mathrm{N}$ dibawah optimal akan membentuk daun - daun berukuran kecil sehingga organ tidak mampu secara optimal melakukan fotosintesis untuk dapat menghasilkan gula.
Hubungan P tersedia dengan produktivitas tanaman tebu

Gambar 4 menunjukkan persamaan hubungan positif antara $\mathrm{P}$ tersedia dengan produktivitas tanaman tebu di lapangan dengan koefisien determinasi mencapai $\left(\mathrm{R}^{2}\right) \quad 0,4952$ dan $\mathrm{r}$ mencapai 0,70. Tanaman tebu akan dapat menghasilkan produktivitas yang tinggi apabila $\mathrm{P}$ tersedia memiliki nilai $>3,80 \mathrm{ppm}$ (berada pada kelas S1) sedangkan produktivitas tebu akan rendah jika nilai $\mathrm{P}$ tersedia berada pada angka $<2,00$ ppm (berada pada kelas S3). Menurut Halliday dan Trenkel (1992), serapan hara $\mathrm{P}$ pada bagian batang tanaman tebu yaitu 26,9 $\mathrm{kg} \mathrm{ha}^{-1}$. Sedangkan Hunsigi (1993) dan Halliday dan Trenkel (1992) dalam 1 ton hasil 
panen tebu terdapat $0,82 \mathrm{~kg} \mathrm{P}$ yang berasal dari dalam tanah, yang menyebabkan pengurasan hara $\mathrm{P}$ yang cukup besar dari dalam tanah pada saat panen. Hardjowigeno (2015) juga menambahkan penyebab rendahnya unsur $\mathrm{P}$ dalam tanah dikarenakan jumlah $\mathrm{P}$ dalam tanah sedikit, sebagian besar terdapat dalam bentuk yang tidak dapat diambil tanaman dan terjadi pengikatan (fiksasi) oleh $\mathrm{Al}$ pada tanah masam atau $\mathrm{Ca}$ pada tanah alkalis. Hara $\mathrm{P}$ dalam tanaman berfungsi sebagai penyedia dan penyimpan energi kimia untuk proses metabolisme dan katabolisme (McCray et al, 2010).

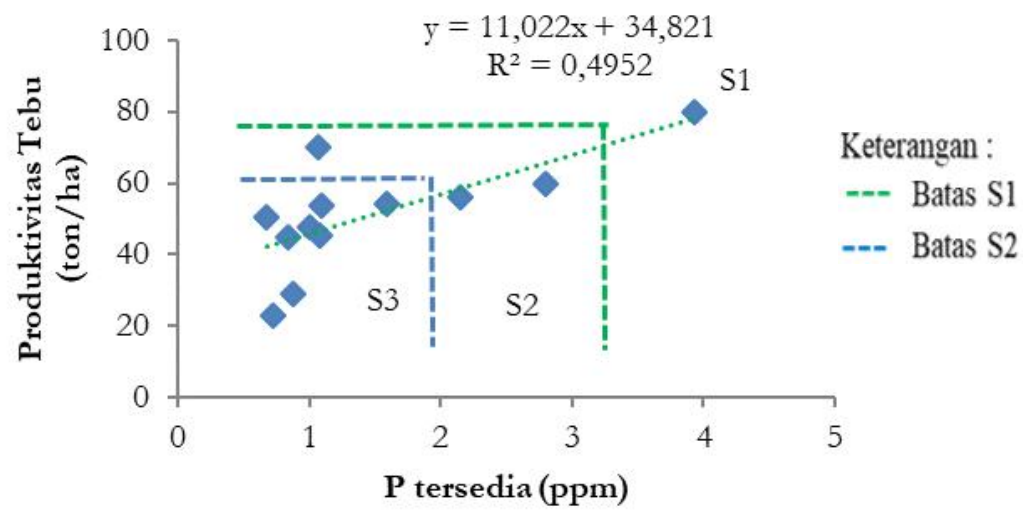

Gambar 4. Hubungan P tersedia dengan produktivitas.

Hubungan $K$ dapat ditukar dengan produktivitas tanaman tebu

Gambar 5 menunjukkan garis persamaan linear hubungan positif antara Kdd dengan produktivitas tanaman tebu di lapangan dengan nilai $\mathrm{R}^{2}$ atau koefisien determinasi 0,4764 dan $\mathrm{r}$ $=0,69$. Berdasarkan gambar diatas, tebu akan berproduksi dengan bagus jika kadar Kdd memiliki nilai $>0,37 \mathrm{cmol} \mathrm{kg} \mathrm{kg}^{-1}$ sedangkan produktivitas tebu akan rendah jika nilai kadar
$\mathrm{Kdd}<0,23 \mathrm{cmol} \mathrm{kg}^{-1}$. Unsur $\mathrm{K}$ berperan penting untuk tanaman tebu dalam proses metabolisme karbohidrat, pembentukan dan translokasi gula, pembentukan protein serta aktivitas sel - sel tanaman (Daryono, 2009). Kekurangan K dapat menyebabkan pertumbuhan tanaman terhambat dengan batang tipis, perakaran terhambat, dan kadar gula dan kualitas nira menurun (Daryono, 2009).

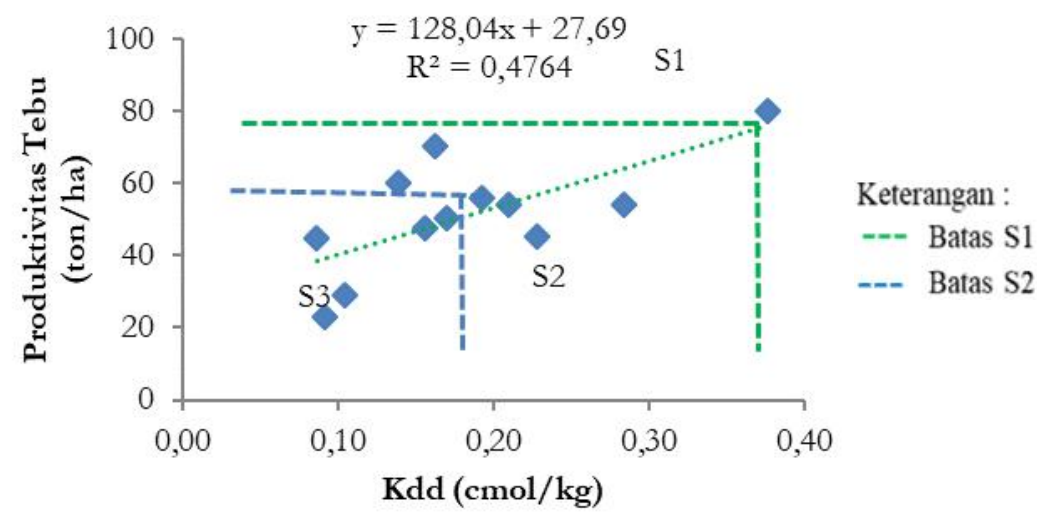

Gambar 5. Hubungan Kdd dengan produktivitas tebu. 


\section{Hubungan kemiringan lereng, kedalaman tanah dengan produktivitas tebu}

Gambar 6 menunjukkan produktivitas tanaman tebu akan semakin menurun dan rendah jika kemiringan lereng melebihi 30\% (kelas S3 sampai $\mathrm{N}$ ) atau mendekati curam, sedangkan produktivitas tebu akan semakin naik jika daerah memiliki lereng dibawah 15\% (kelas S2) atau mendekati datar. Nilai kemiringan lereng yang besar akan mengakibatkan tanah menjadi mudah tererosi atau kehilangan, menurut Martono (2004), lereng yang semakin curam dan semakin panjang akan meningkatkan kecepatan aliran permukaan dan volume air permukaan semakin besar, sehingga benda yang bisa diangkut akan lebih banyak.

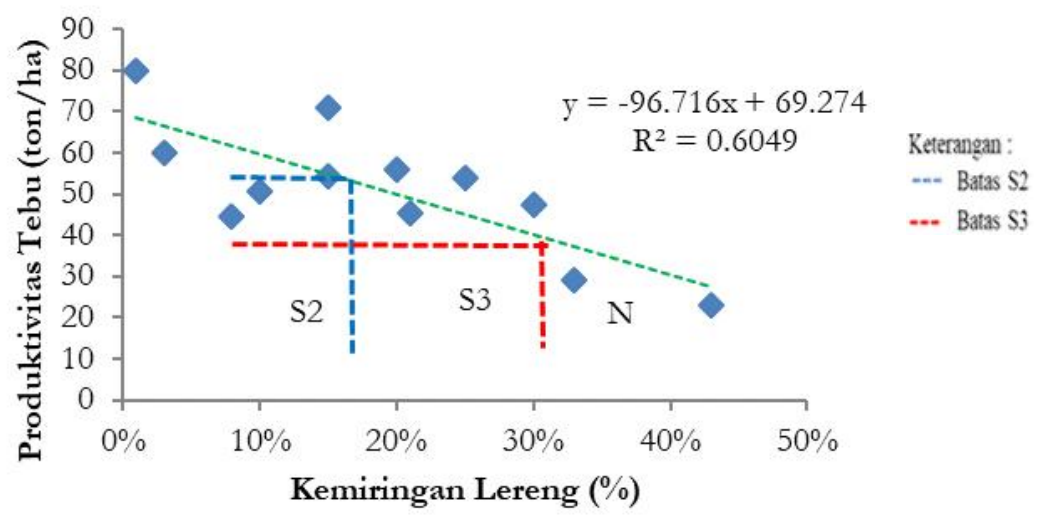

Gambar 6. Hubungan kemiringan lereng dengan produktivitas tebu.

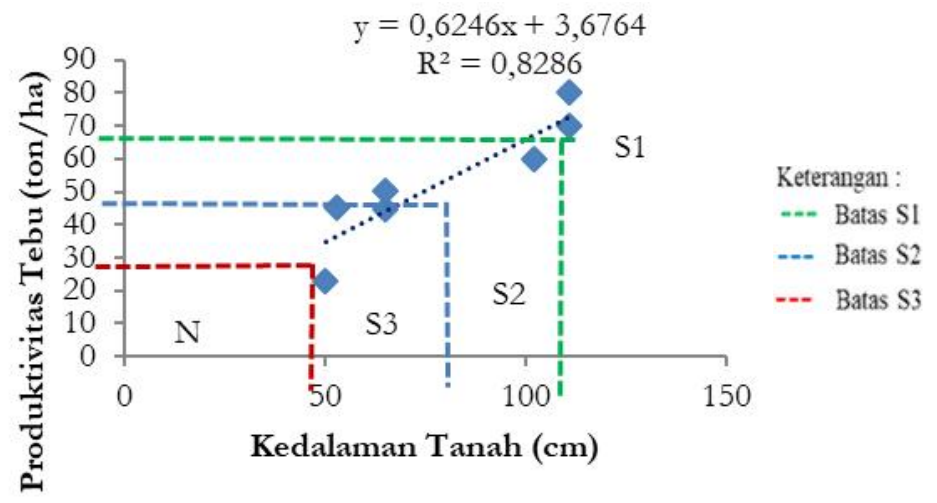

Gambar 7. Hubungan kedalaman tanah dengan produktivitas tebu.

Gambar 7 menunjukkan diagram hubungan kedalaman tanah dengan produktivitas tanaman tebu. Tanaman tebu akan menghasilkan produktivitas tanaman yang tinggi dan bagus jika kedalaman tanah $\geq 110$ cm dan akan berada pada kelas S1, sedangkan produktivitas tanaman akan rendah dan buruk (berada pada kelas N) jika kedalaman tanah < $50 \mathrm{~cm}$. Menurut Nugroho (2006), tanah dengan kedalaman perakaran dan solum tanah yang rendah memiliki kecenderungan persebaran akar menyebar secara horizontal dan akar yang tumbuh secara vertikal untuk penguat tanaman dan menjangkau lebih dalam lapisan tanah yang lebih sedikit. Sedangkan akar yang memiliki kedalaman tanah (solum tanah) yang lebih dalam akar cenderung menyebar seimbang antara vertikal dan horizontal, selain itu 
persebaran akar menyebar ke segala bidang tanah. Hal ini akan membuat jangkauan nutrisi akar menjadi lebih luas, kekuatan tanaman lebih kuat karena pertumbuhan akar yang mengarah vertikal lebih banyak sehingga pertumbuhan tanaman lebih cepat dan kuat. Nilai $R^{2}$ dan $r$ berturut-turut sebesar 0,6049 dan 0,775 untuk kemiringan lereng, 0,8286 dan 0,746 untuk kedalaman tanah.

\section{Penyusunan kriteria kesesuaian lahan dengan metode boundary line}

Penyusunan kriteria kesesuaian lahan dengan metode boundary line dilakukan setelah membuat grafik persamaan linear yang menunjukkan hubungan antara karakteristik lahan (variabel $\mathrm{x}$ ) yang meliputi c-organik, $\mathrm{N}$ total, $\mathrm{P}$ tersedia, Kdd, kemiringan lereng dan kedalaman tanah dengan produktivitas tanaman tebu (variabel y) di lapangan (Gambar 2 - 7) berdasarkan batas kelas produktivitas tebu yang telah ditetapkan (penarikan garis batas setiap kelasnya). Modifikasi dilakukan atas dasar hasil kesesuaian lahan aktual yang masih terdapat kelas yang masih belum sesuai dengan persentase produksi. Setelah dibuat grafik hubungan antara variabel $\mathrm{x}$ dan $\mathrm{y}$, sebelum ditarik garis batas, batas minimum dari kelas S1, S2, S3 dan $\mathrm{N}$ harus ditentukan terlebih dahulu dengan mengalikan batas minimum dari kelas produksi (S1 80\%, S2 60\%, S3 40\%, dan $\mathrm{N}$ dibawah $40 \%$ ) dengan potensi produksi (94,3 ton/ha), maka didapat kelas $\mathrm{S} 1$ memiliki batas minimum $75,44 \mathrm{t} \mathrm{ha}^{-1}$, S2 56,58 $\mathrm{t} \mathrm{ha}^{-1}$, S3 37,72 $\mathrm{t} \mathrm{ha}^{-1}$ sedangkan $\mathrm{N}$ dibawah $37,72 \mathrm{t} \mathrm{ha}^{-1}$. Berikut merupakan hasil modifikasi berdasarkan metode boundary line.

Tabel 2. Karakteristik lahan modifikasi berdasarkan metode boundary line.

\begin{tabular}{lcccc}
\hline Kualitas lahan / Karakteristik lahan & \multicolumn{4}{c}{ Kelas Kesesuaian Lahan } \\
\cline { 2 - 5 } & S1 & S2 & S3 & N \\
\hline $\begin{array}{l}\text { Media Perakaran (rc) } \\
\text { *Kedalaman Tanah (cm) }\end{array}$ & $>110$ & $85-110$ & $50-85$ & $<50$ \\
Retensi Hara (nr) & & & & \\
*C-Organik (\%) & - & $>1,16$ & $0,60-1,16$ & $<0,60$ \\
Hara Tersedia (na) & $>0,18$ & $0,12-0,18$ & $0,04-0,12$ & $<0,04$ \\
*N total (\%) & $>3,80$ & $2-3,80$ & $<2$ & - \\
*P tersedia (ppm) & $>0,37$ & $0,23-0,37$ & $<0,23$ & - \\
*Kdd (cmol kg-1) & & $<12$ & $12-32$ & $>32$ \\
Bahaya Erosi (eh) & - & $<12$ & \\
*Lereng (\%) & & & & \\
\hline
\end{tabular}

Ket : - : tidak dapat diasumsikan; *: modifikasi boundary line.

\section{Validasi kelas kesesuaian lahan tanaman tebu berdasarkan metode boundary line}

Hasil matching yang dilakukan dengan kriteria kesesuaian lahan hasil modifikasi boundary line, kelas kesesuaian lahan (KKL) menunjukkan hasil yang berbeda dengan KKL sebelum di modifikasi, dimana pada KKL hasil modifikasi, SPL 1 yang semula memiliki KKL S3 (Sesuai Marginal) berubah menjadi KKL S2 (Cukup Sesuai), sementara SPL yang lain masih sama berupa KKL S3 (Sesuai Marginal) dan N (Tidak Sesuai). Hasil uji tingkat keakuratan
KKL dibandingkan dengan KKL persentase produksi didapatkan tingkat akurasi KKL berdasarkan metode boundary line sebesar 75\%, dengan total SPL yang cocok dengan KKL persentase produksi sebanyak 9 SPL. Menurut National Park Service Vegetation Inventory (2010), hasil dikatakan akurat apabila nilai accuration assessment yang dihasilkan lebih dari $80 \%$. Jika hasil yang dihasilkan kurang dari $80 \%$ maka masih belum dikatakan akurat. Berikut hasil kelas kesesuaian lahan dengan menggunakan metode boundary line 
Tabel 3. Hasil kelas kesesuaian lahan metode boundary line.

\begin{tabular}{|c|c|c|c|c|c|}
\hline SPL & Jenis Tanah & $\begin{array}{l}\text { Sub Kelas } \\
\text { Kesesuaian } \\
\text { Lahan }\end{array}$ & $\begin{array}{c}\text { Faktor } \\
\text { Pembatas }\end{array}$ & KKL & $\begin{array}{c}\text { Persentase } \\
\text { Produksi }\end{array}$ \\
\hline 1 & $\begin{array}{l}\text { Eutric } \\
\text { Humudept }\end{array}$ & S2-na & $\mathrm{N}$ total & S1 & $84,83 \%$ \\
\hline 2 & Typic Humudept & S3-na & Kdd & S2 & $63,62 \%$ \\
\hline 3 & Typic Humudept & S3-nr/na/eh & $\begin{array}{l}\text { C-Organik, } \mathrm{N} \text { total, } \mathrm{P} \\
\text { tersedia, Lereng, Bahaya } \\
\text { Erosi }\end{array}$ & S3 & $57,13 \%$ \\
\hline 4 & Typic Humudept & S3-nr/na/eh & $\begin{array}{c}\text { C-Organik, } \mathrm{N} \text { total, } \mathrm{P} \\
\text { tersedia, Kdd, Lereng, } \\
\text { Bahaya Erosi }\end{array}$ & S3 & $50,28 \%$ \\
\hline 5 & Typic Humudept & S3-na/eh & $\begin{array}{c}\text { Kdd, Lereng, Bahaya } \\
\text { Erosi }\end{array}$ & S3 & $59,28 \%$ \\
\hline 5 & Lithik Hapludoll & $\mathrm{S} 3-\mathrm{rc} / \mathrm{nr} / \mathrm{na} / \mathrm{eh}$ & $\begin{array}{c}\text { Kedalaman Tanah, C- } \\
\text { Organik, N total, P } \\
\text { tersedia, Lereng, Bahaya } \\
\text { Erosi }\end{array}$ & S3 & $47,92 \%$ \\
\hline 6 & Typic Hapludoll & N-eh & Lereng & $\mathrm{N}$ & $30,93 \%$ \\
\hline 7 & Lithik Hapludoll & $\mathrm{N}$-nr/na/eh & $\begin{array}{l}\text { C-Organik, } \mathrm{N} \text { total , } \\
\text { Lereng, Bahaya Erosi }\end{array}$ & $\mathrm{N}$ & $24,39 \%$ \\
\hline 8 & Typic Humudept & S3-oa/na/eh & $\begin{array}{l}\text { Drainase, } P \text { tersedia, } \\
\text { Kdd, Lereng }\end{array}$ & S3 & $57,43 \%$ \\
\hline 9 & Typic Calciudoll & $\mathrm{S} 3-\mathrm{rc} / \mathrm{nr} / \mathrm{na}$ & $\begin{array}{l}\text { Kedalaman Tanah, C- } \\
\text { Organik, N total, P } \\
\text { tersedia, Kdd }\end{array}$ & S3 & $47,43 \%$ \\
\hline 10 & Typic Humudept & S3-nr/na/eh & $\begin{array}{l}\text { C-Organik, N total, P } \\
\text { tersedia, Kdd, Lereng }\end{array}$ & S3 & $74,51 \%$ \\
\hline 10 & Typic Hapludoll & $\mathrm{S} 3-\mathrm{rc} / \mathrm{na}$ & $\begin{array}{l}\text { Kedalaman Tanah, N } \\
\text { total, P tersedia, Kdd }\end{array}$ & S3 & $53,50 \%$ \\
\hline 11 & Typic Humudept & - & - & - & - \\
\hline 12 & Typic Humudept & - & - & - & - \\
\hline 13 & Typic Humudept & - & - & - & - \\
\hline
\end{tabular}

Keterangan : - : tidak dilakukan proses evaluasi lahan dikarenakan tidak terdapat komoditas tanaman tebu.

\section{Penyusunan kriteria kesesuaian lahan dengan metode kelas persentase produksi}

Penyusunan kriteria kesesuaian lahan dengan metode kelas persentase produksi dilakukan karena berdasarkan hasil kelas kesesuaian lahan metode boundary line, jika dilihat dari tingkat keakuratannya, nilai akurasi hasil kelas kesesuaian lahan metode boundary line masih dibawah $80 \%$ (nilai akurasi hanya $75 \%$ ). Untuk itu perlu dilakukan penyesuaian kembali kriteria kesesuaian lahan untuk tanaman tebu menggunakan modifikasi kelas persentase produksi dengan melihat faktor pembatas yang paling membatasi daerah tersebut sehingga tidak dapat dinaikkan kelas kesesuaian lahannya. Berdasarkan hasil matching kriteria kesesuaian lahan modifikasi boundary line didapat bahwa yang paling banyak membatasi SPL pada daerah penelitian adalah karakteristik lahan c-organik, $\mathrm{N}$ total, $\mathrm{P}$ tersedia, Kdd, dan kemiringan lereng.

Penyusunan kriteria kesesuaian lahan dengan metode kelas persentase produksi dilakukan melalui Pendekatan modifikasi dengan melihat persentasi produksi dilihat berdasarkan persentase minimum dari masing masing kelas kesesuaian lahan berdasarkan 
produksi dengan kriteria untuk S1 memiliki persentase produksi minimum yaitu $80 \%$, S2 memiliki persentase produksi minimum 60\%, S3 memiliki persentase produksi minimum $40 \%$ dan $\mathrm{N}<40 \%$ (Khrisnohadi, 2008).
Persentase produksi tersebut, kemudian dikalikan (korelasi positif) atau dibagi (korelasi negatif) dengan nilai minimum dari kelas kesesuaian lahan tanaman tebu.

Tabel 4. Karakteristik lahan modifikasi berdasarkan metode kelas persentase produksi.

\begin{tabular}{lcccc}
\hline Kualitas lahan / Karakteristik lahan & \multicolumn{4}{c}{ Kelas Kesesuaian Lahan } \\
\cline { 2 - 5 } & S1 & S2 & S3 & N \\
\hline $\begin{array}{l}\text { Media Perakaran (rc) } \\
\text { ***Kedalaman Tanah (cm) }\end{array}$ & $>110$ & $85-110$ & $50-85$ & $<50$ \\
$\begin{array}{l}\text { Retensi Hara (nr) } \\
\text { **-Organik (\%) }\end{array}$ & - & $*>0,70$ & $* 0,60-0,70$ & $<0,60$ \\
Hara Tersedia (na) & $*>0,14$ & $* 0,07-0,14$ & $* 0,04-0,07$ & $<0,04$ \\
$* *$ N total (\%) & $>3,80$ & $* 1,2-3,80$ & $*<1,2$ & - \\
$* *$ P tersedia (ppm) & $>0,37$ & $* 0,14-0,37$ & $*<0,14$ & - \\
$* *$ Kdd (cmol kg-1) & - & $*<20$ & $* 20-32$ & $>32$ \\
Bahaya Erosi (eh) & - & $* * 20$ & \\
$* *$ Lereng (\%) &
\end{tabular}

Keterangan : ${ }^{* * *}$ : tetap; ${ }^{* *}:$ Karakteristik lahan yang diubah; ${ }^{*}:$ Kelas Kesesuaian Lahan yang diubah.

Validasi kelas kesesuaian lahan tanaman tebu berdasarkan metode kelas persentase produksi

Tabel di bawah ini merupakan tabel hasil kelas kesesuaian lahan berdasarkan modifikasi kelas persentase produksi. Kelas Kesesuaian Lahan (KKL) untuk tanaman tebu modifikasi berdasarkan metode kelas persentase produksi dilakukan setelah memodifikasi ulang kriteria kesesuaian lahan yang berasal dari metode boundary line kemudian dimodifikasi kembali dengan menyesuaikan kelas persentase produksi. Dilakukan proses matching kembali.

Hasil matching didapatkan kelas kesesuaian lahan tanaman tebu di daerah penelitian yang mendekati kelas persentase produksi tanaman tebu di lapangan. SPL 1 yang semula, jika dilakukan proses evaluasi dengan kriteria hasil metode boundary line didapatkan kelas S2, namun setelah dilakukan modifikasi penyesuaian kelas produksi KKL SPL 1 berubah menjadi S1. Begitu juga SPL 2 yang semula termasuk kedalam KKL S3, setelah dimodifikasi kembali, dapat naik KKLnya menjadi S2. Sementara SPL 10 (Typic Humudept) masih tetap menunjukkan kelas S3.

Hasil uji tingkat keakuratan KKL dibandingkan dengan KKL persentase produksi didapatkan tingkat akurasi KKL berdasarkan metode kelas persentase produksi sebesar 91\%, dengan total SPL yang cocok dengan KKL persentase produksi sebanyak 11 SPL. Hasil ini menghasilkan nilai yang akurat dikarenakan nilai akurasi $>80 \%$.

Tabel 5. Hasil kelas kesesuaian lahan metode kelas persentase produksi.

\begin{tabular}{|c|c|c|c|c|c|}
\hline SPL & Jenis Tanah & $\begin{array}{c}\text { Sub Kelas } \\
\text { Kesesuaian Lahan }\end{array}$ & Faktor Pembatas & KKL & $\begin{array}{c}\text { Persentase } \\
\text { Produksi }\end{array}$ \\
\hline 1 & Eutric Humudept & S1 & - & S1 & $84,83 \%$ \\
\hline 2 & Typic Humudept & $\mathrm{S} 2-\mathrm{oa} / \mathrm{rc} / \mathrm{nr} / \mathrm{na} / \mathrm{lp}$ & $\begin{array}{c}\text { Drainase, Kedalaman } \\
\text { Tanah, Kejenuhan } \\
\text { Basa, N total, P } \\
\text { tersedia, Kdd, Batuan } \\
\text { Permukaan, } \\
\text { Singkapan Batuan }\end{array}$ & S2 & $63,62 \%$ \\
\hline 3 & Typic Humudept & S3-na/eh & Lereng, Bahaya & S3 & $57,13 \%$ \\
\hline
\end{tabular}


Jurnal Tanah dan Sumberdaya Lahan Vol 6 No 2 : 1361-1374, 2019

e-ISSN:2549-9793, doi: 10.21776/ub.jts1.2019.006.2.17

\begin{tabular}{|c|c|c|c|c|c|}
\hline SPL & Jenis Tanah & $\begin{array}{c}\text { Sub Kelas } \\
\text { Kesesuaian Lahan }\end{array}$ & Faktor Pembatas & KKL & $\begin{array}{c}\text { Persentase } \\
\text { Produksi }\end{array}$ \\
\hline 4 & Typic Humudept & S3-na/eh & $\begin{array}{c}\text { Erosi, P tersedia } \\
\mathrm{N} \text { total, P tersedia, } \\
\text { Lereng, Bahaya Erosi }\end{array}$ & S3 & $50,28 \%$ \\
\hline 5 & Typic Humudept & S3-eh & Bahaya Erosi & S3 & $59,28 \%$ \\
\hline 5 & Lithik Hapludoll & $\mathrm{S} 3-\mathrm{rc} / \mathrm{na} / \mathrm{eh}$ & $\begin{array}{c}\text { Kedalaman Tanah, P } \\
\text { tersedia, Lereng, } \\
\text { Bahaya Erosi }\end{array}$ & S3 & $47,92 \%$ \\
\hline 6 & Typic Hapludoll & $\mathrm{N}$-eh & Lereng & $\mathrm{N}$ & $30,93 \%$ \\
\hline 7 & Lithik Hapludoll & N-nr/na/eh & $\begin{array}{l}\text { C-Organik, N total, } \\
\text { Lereng, Bahaya Eosi }\end{array}$ & $\mathrm{N}$ & $24,39 \%$ \\
\hline 8 & Typic Humudept & S3-oa & Drainase & S3 & $57,43 \%$ \\
\hline 9 & Typic Calciudoll & $\mathrm{S} 3-\mathrm{rc} / \mathrm{nr} / \mathrm{na}$ & $\begin{array}{l}\text { Kedalaman Tanah, } \\
\text { C-Organik, P } \\
\text { tersedia, Kdd }\end{array}$ & S3 & $47,43 \%$ \\
\hline 10 & Typic Humudept & S3-na & P tersedia & S3 & $74,51 \%$ \\
\hline 10 & Typic Hapludoll & $\mathrm{S} 3-\mathrm{rc} / \mathrm{na}$ & $\begin{array}{l}\text { Kedalaman Tanah, } \mathrm{N} \\
\text { total, } \mathrm{P} \text { tersedia }\end{array}$ & S3 & $53,50 \%$ \\
\hline 11 & Typic Humudept & - & - & - & - \\
\hline 12 & Typic Humudept & - & - & - & - \\
\hline 13 & Typic Humudept & - & - & - & - \\
\hline
\end{tabular}

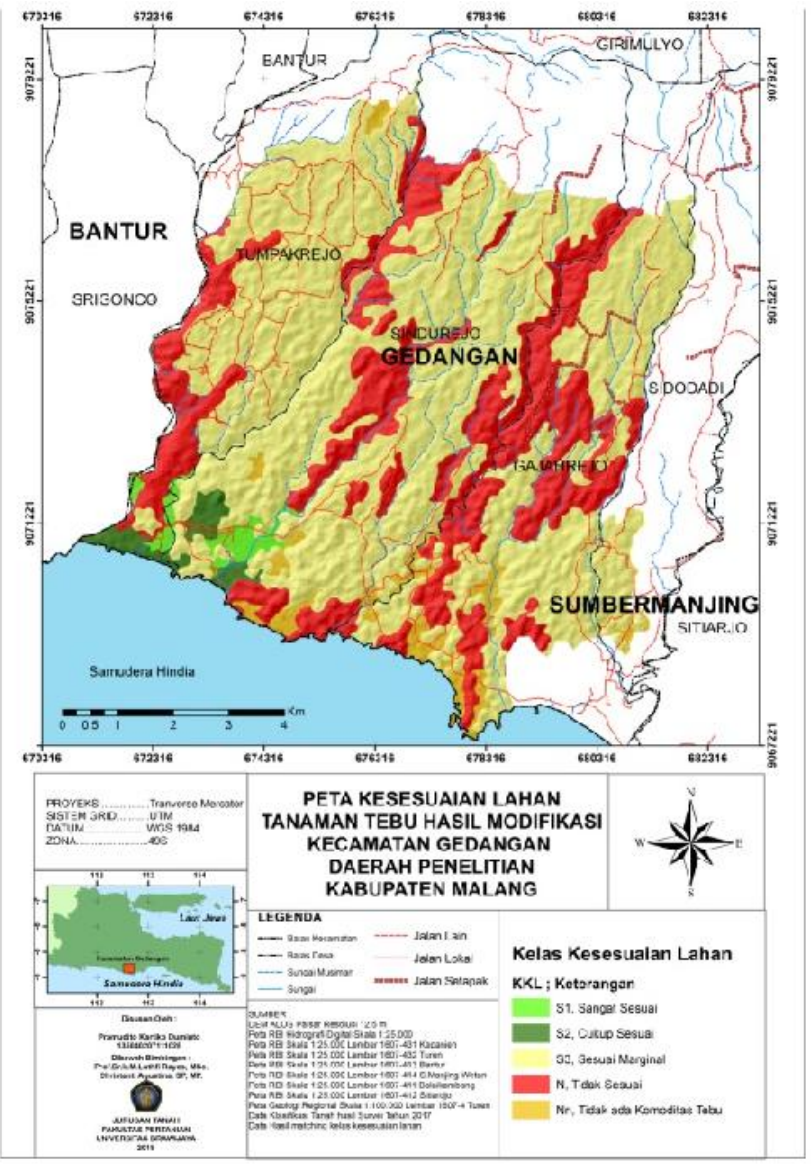

Gambar 8. Peta kesesuaian lahan tanaman tebu hasil modifikasi pada daerah penelitian Keterangan : - tidak dilakukan proses evaluasi lahan dikarenakan tidak terdapat komoditas tanaman tebu. 
Jurnal Tanah dan Sumberdaya Lahan Vol 6 No 2 : 1361-1374, 2019

e-ISSN:2549-9793, doi: 10.21776/ub.jts1.2019.006.2.17

Kriteria kesesuaian lahan tanaman tebu varietas BL (Bululawang) lahan karst formasi Wonosari

\begin{tabular}{|c|c|c|c|c|}
\hline Kualitas Lahan/ & Kelas & Kesesu & aian & Lahan \\
\hline Karakteristik Lahan & S1 & $\mathbf{S} 2$ & S3 & $\mathbf{N}$ \\
\hline \multicolumn{5}{|l|}{ Temperatur (tc) } \\
\hline Temperatur rerata $\left({ }^{\circ} \mathrm{C}\right)$ & $24-30$ & $\begin{array}{l}30-32 \\
22-24\end{array}$ & $\begin{array}{l}32-34 \\
21-22\end{array}$ & $>34$ \\
\hline \multicolumn{5}{|l|}{ Ketersediaan Air (wa) } \\
\hline Curah Hujan (mm) & $>1.600$ & $1.100-1.600$ & $800-1.100$ & $<800$ \\
\hline Lamanya masa kering (Bln) & $1-4$ & $\begin{array}{c}<1 \\
4-5\end{array}$ & $5-6$ & $>6$ \\
\hline \multicolumn{5}{|l|}{ Ketersediaan Oksigen(oa) } \\
\hline Drainase & Baik, Sedang & Agak Lambat & $\begin{array}{c}\text { Lambat, Agak } \\
\text { cepat }\end{array}$ & $\begin{array}{c}\text { Sangat Lambat, } \\
\text { Cepat }\end{array}$ \\
\hline \multicolumn{5}{|l|}{ Media Perakaran (rc) } \\
\hline Tekstur & Halus, Sedang & Agak Halus & Agak Kasar & Kasar \\
\hline \multirow[t]{2}{*}{ Kedalaman tanah $(\mathrm{cm})$} & $>100$ & $75-100$ & $50-75$ & $<50$ \\
\hline & $>110$ & $85-110$ & $50-85$ & \\
\hline Bahan Kasar $\%$ & $<15$ & $15-35$ & $35-55$ & $>55$ \\
\hline \multicolumn{5}{|l|}{ Retensi Hara (nr) } \\
\hline KTK total $(\mathrm{cmol})$ & $>16$ & $5-16$ & $<5$ & - \\
\hline Kejenuhan Basa $(\mathrm{KB}) \%$ & $>50$ & $35-50$ & $<35$ & - \\
\hline \multirow[t]{2}{*}{$\mathrm{pH} \mathrm{H} 2 \mathrm{O}$} & $5,5-7,5$ & $5,0-5,5$ & $<5,0$ & - \\
\hline & & $7,5-8,0$ & $>8,0$ & \\
\hline \multirow[t]{2}{*}{ C-Organik (\%) } & $>1,20$ & $0,80-1,20$ & $<0,80$ & - \\
\hline & & $>0,70$ & $0,60-0,70$ & $<0,60$ \\
\hline \multicolumn{5}{|l|}{ Hara Tersedia (na) } \\
\hline \multirow[t]{2}{*}{$\mathrm{N}$ total $(\%)$} & $>0,20$ & $0,10-0,20$ & $<0,10$ & - \\
\hline & $>0,14$ & $0,07-0,14$ & $0,04-0,07$ & $<0,04$ \\
\hline \multirow[t]{2}{*}{$\mathrm{P}$ tersedia $(\mathrm{ppm})$} & $>25$ & $6-25$ & $<6$ & - \\
\hline & $>3,80$ & $1,20-3,80$ & $<1,20$ & - \\
\hline $\mathrm{Kdd}\left(\mathrm{cmol} \mathrm{kg}^{-1}\right)$ & $>0,37$ & $0,14-0,37$ & $<0,14$ & - \\
\hline \multicolumn{5}{|l|}{ Toksisitas (xc) } \\
\hline Salinitas $\left(\mathrm{dS} \mathrm{m}^{-1}\right)$ & $<3$ & $3-4$ & $4-5$ & $>6$ \\
\hline \multicolumn{5}{|l|}{ Sodisitas (xn) } \\
\hline Alkalinitas /ESP\% & $<10$ & $10-15$ & $15-20$ & $>20$ \\
\hline \multicolumn{5}{|l|}{ Bahaya Erosi (eh) } \\
\hline \multirow[t]{2}{*}{ Lereng $\%$} & $<8$ & $8-16$ & $16-30$ & $>30$ \\
\hline & & $<20$ & $20-32$ & $>32$ \\
\hline Bahaya Erosi & - & Sangat Ringan & Ringan - Sedang & $\begin{array}{c}\text { Berat - Sangat } \\
\text { Berat }\end{array}$ \\
\hline \multicolumn{5}{|l|}{ Bahaya Banjir (fh) } \\
\hline Tinggi $(\mathrm{cm})$ & - & - & 25 & $>25$ \\
\hline Lama (hari) & - & - & $<7$ & $\geq 7$ \\
\hline \multicolumn{5}{|l|}{ Penyiapan Lahan (lp) } \\
\hline Batuan Permukaan (\%) & $<5$ & $5-15$ & $15-40$ & $>40$ \\
\hline Singkapan Batuan (\%) & $<5$ & $5-15$ & $15-25$ & $>25$ \\
\hline
\end{tabular}

Keterangan: Tekstur : Halus : Liat Berpasir, Liat, Liat Berdebu, Agak Kasar : Lempung berpasir, Agak Halus : Lempung berliat, Lempung liat berpasir, Lempung liat berdebu Kasar : Pasir, Pasir berlempung, Sedang : Lempung berpasir sangat halus, Lempung, Lempung berdebu, Debu, Sangat Halus : Liat (tipe liat $2: 1$ ). Keterangan: Tulisan cetak tebal dengan font miring merupakan hasil modifikasi criteria (Sumber : Kriteria Kesesuaian Lahan menurut Djaenuddin et al. (2003 dan 2011); Kriteria Kesesuaian Lahan menurut Charrupat et al. (2002); Kriteria Kesesuaian Lahan menurut Siswanto (2006); modifikasi kriteria kesesuaian lahan berdasarkan metode boundary line dan kelas persentase produksi). 


\section{Jurnal Tanah dan Sumberdaya Lahan Vol 6 No 2 : 1361-1374, 2019 \\ e-ISSN:2549-9793, doi: 10.21776/ub.jts1.2019.006.2.17}

\section{Kesimpulan}

1. Kelas Kesesuaian Lahan tanaman tebu pada lahan karst formasi wonosari menghasilkan 3 versi, yaitu Kelas kesesuaian lahan sebelum di modifikasi dengan KKL S3 (Sesuai Marginal) dan N (Tidak Sesuai), Kelas kesesuaian lahan setelah di modifikasi metode boundary line dengan KKL S2 (Cukup Sesuai), S3 (Sesuai Marginal) dan N (Tidak Sesuai) dan kelas kesesuaian lahan setelah modifikasi kelas persentase produksi dengan KKL S1 (Sangat Sesuai), S2 (Cukup Sesuai), S3 (Sesuai Marginal) dan N (Tidak Sesuai)

2. Terdapat 6 karakteristik lahan yang paling berpengaruh terhadap produktivitas tanaman tebu di lapangan, 6 karakteristik lahan tersebut yaitu C-organik, N-total, P tersedia, Kdd, kedalaman tanah dan kemiringan lereng, yang masing - masing memiliki nilai korelasi dan nilai koefisien determinasi atau $r$ dan $\mathrm{R}^{2} \geq 0,5$.

3. Modifikasi metode boundary line menghasilkan kelas S2, S3 dan $\mathrm{N}$ dengan tingkat keakuratan hasil sebesar 75\% lalu dilanjutkan dengan modifikasi metode kelas persentase produksi dengan keakuratan hasil kelas kesesuaian lahan sebesar 91\%. Penyusunan kriteria kesesuaian lahan menghasilkan kriteria kedalaman tanah dengan kelas S1 $(>110 \mathrm{~cm}), \mathrm{S} 2(85-110 \mathrm{~cm})$, S3 $(50-85 \mathrm{~cm}), \mathrm{N}(<50 \mathrm{~cm})$. C-organik S2 $(>0,70 \%), \mathrm{S} 3(0,60-0,70 \%), \mathrm{N}(<0,60 \%)$. $\mathrm{N}$ total S1 (>0,14\%), S2 (0,07-0,14\%), S3 $(0,04-0,07 \%)$ dan $\mathrm{N}(<0,04 \%)$. P tersedia kelas S1 (> 3,80 ppm) S2 (1,20-3,80 ppm), $\mathrm{S} 3(<1,20 \mathrm{ppm})$. Kdd kelas S1 $>0,37 \mathrm{cmol}$ $\left.\mathrm{kg}^{-1}\right)$ S2 $\left(0,14-0,37 \mathrm{cmol} \mathrm{kg}^{-1}\right), \mathrm{S} 3(<0,14$ cmol kg-1).

\section{Ucapan Terima Kasih}

Terima kasih saya ucapkan kepada masyarakat dan pemerintah daaerah khususnya Desa Tumpakrejo, Sindurejo, Gajahrejo dan Desa Sidodadi Kecamatan Gedangan Kabupaten Malang yang telah mengizinkan dan membantu berjalannya penelitian ini dan juga saya mengucapkan terima kasih kepada Pabrik Gula Rajawali I Krebet Baru yang telah membantu saya dalam mengumpulkan data produksi tebu. Tak lupa juga saya sampikan terima kasih kepada rekan penelitian saya Andre dan Arum serta teman-teman saya Iman, Mualif, Eman, Yogi dan Halyta yang telah membantu saya dalam penelitian ini sehingga dapat selesai sesuai waktu yang telah ditentukan.

\section{Daftar Pustaka}

Charrupat, T. and Mongkolsawat, C. 2002. Land evaluation for economic crops of Lam Phra Phloeng Watershed in Thailand using GIS modeling. Asian Journal of Geoinformatics. 3(3) : 89-100.

Chen, S.S. and Yung, T.C. 1990. The effects of organic matter on soil properties. Paper presented at Seminar on the Use of Organic Fertilizers in Crop Production, Suweon, South Korea.18-24 Jun.1990. Suweon. South Korea.

Daryono, H. 2009. Potensi, permasalahan dan kebijakan yang diperlukan dalam pengelolaan hutan dan lahan rawa gambut secara lestari. Jurnal Analisis Kebijakan Kehutanan 6 (20) : 71 $-101$.

Dinas Pertanian dan Perkebunan. 2017. Produksi Perkebunan Rakyat di Jawa Timur. Dinas Pertanian dan Perkebunan Kabupaten Malang. Kepanjen.

Djaenuddin, D., Marwan, H., Subagyo, H. dan Hidayat, A. 2003. Petunjuk Teknis Evaluasi Lahan untuk Komoditas Petanian. Edisi IV, BPT, PPTA. Bogor.

Halliday, D.J. and Trenkel, M.E.1992. Word Fertilizer Use Manual. International Fertilizer Industry Association. Paris.

Hardjowigeno, S. 2015. Ilmu Tanah. Edisi Baru. Akademika Pressindo. Jakarta.

Hunsigi, G. 1993. Production of Sugarcane Theory and Practices. Springer-Verlag. Berlin.

Krisnohadi, A. 2008. Pembangunan Kriteria Kesesuaian Lahan untuk Jambu Mete (Anacardium occidentale L.) dan Optimalisasi Manajemen Spesifik Lokasi Usaha Tani Jambu Mete di Kabupaten Dompu. M.S. thesis. Program Pascasarjana, Institut Pertanian Bogor, Bogor, Indonesia.

Martono. 2004. Pengaruh Intensitas Hujan dan Kemiringan Lereng terhadap Laju Kehilangan Tanah pada Tanah Regosol Kelabu. Tesis. Universitas Diponegoro. Semarang.

McCray, J.M., Rice, R.W., Luo, Y. And J, S. 2010. sugarcane response to phosporus fertilizer on Everglades Histosols. Agronomy Journal. 102 (1) : $1468-1477$.

National Park Service Vegetation Inventory (NPSVI).2010. Thematic Accurary Assessment Procedures. U.S. Department of the Interior National Park Service. Colorado, USA. 
Nugroho, Y. 2006. Sistem Perakaran Sengon Laut Nielsen pada Lahan Bekas Penambangan Tipe C di Kecamatan Cangkringan Kabupaten Sleman. Daerah Istimewa Yogyakarta.

Rukmana, R.H. 2015. Untung Selangit dari Agribisnis Tebu. Lily Publisher. Yogyakarta.

Siswanto. 2006. Evaluasi Sumber daya Lahan. UPN Press. UPN Veteran Jawa Timur.Surabaya.

Soil Survey Staff. 2014. Keys to Soil Taxonomy. 8 th edition. Natural Resources Conservation Service. USDA. p 326.

Surono, B.T. dan Sudarno. 1992. Peta Geologi Lembar Turen Skala 1: 100.000. Pusat Penelitian dan Pengembangan Geologi. Bandung.
Tisdale, S.L., Nelson, W.L., Beaton,J.D. and Havlin, J.L. 1993. Soil fertility and fertilizers. Fifth Edition. Macmillan Pub. Co. New York, Canada, Toronto, Singapore, pp. 462-607.

Van Bemmelen, R.W. 1949. The Geology of Indonesia. Martinus Nyhoff. The Haque. Nederland.

Zaini, Z., Diah, W.S. dan Syam, M. 2004. Petunjuk Lapang Pengelolaan Tanaman Terpadu Padi Sawah. Meningkatkan Hasil dan Pendapatan, Menjaga Kelestarian Lingkungan. BPTP Sumatera Utara, BPTP Nusa Tenggara Barat, Balai Penelitian Tanaman Padi, dan IRRI. 57 hlm. 